\title{
An Analysis of the Strategic Planning Process at Large Hub Airports in the United States
}

\author{
Kimberly A. Kenville \\ University of North Dakota
}

\begin{abstract}
The focus of this research study was to test the theory of strategic planning in relation to the nation's 31 large hub airports. Strategic planning is reported to increase an organization's performance, operations, and overall effectiveness. Strategic planning has been used in the private and public sectors for decades. Airports are an often over-looked industry falling uniquely between the public and private sectors. The 31 large hub airports have a significant impact on the nation's economy and are the main catalyst for air transportation in the United States. Therefore, it is prudent to study this industry, and to determine the overall effectiveness of strategic planning for airports. The research indicates that large hub airports regularly engage in strategic planning and the plans they have developed and implemented have had a positive impact on the airport's overall performance and effectiveness.

\section{INTRODUCTION}

The purpose of this research was to determine whether the largest 31 public-use airports in the United States have engaged in the strategic planning process, and to ascertain the overall effectiveness of strategic planning in response to the current (2000-present) aviation economic crisis. Strategic planning has been used in the private business sector for decades and has been utilized recently in public sector organizations. Strategic planning is said to increase an organization's financial performance and longevity (Bryson \& Einsweiler, 1987). Assuming that strategic planning is effective and enhances sustainability, it appears that public organizations should adopt the process of strategic planning (Poister \& Streib, 1999).

There are obvious differences in the private and public sectors but many aspects of the strategic planning process are germane to both types of organizations. The federal government, as well as many state governments, has mandated that strategic planning be tied to performance metrics for all of its agencies (Government Accounting Office, 2004). This research takes an in-depth view of the nation's 31 largest airports to determine whether or not these organizations have initiated strategic planning, and if they have, to what extent has the process impacted performance and operations.

Airports straddle a unique ownership/management structure; a large

majority of public-use airports in the United States are owned and operated by cities and counties. Many airports have undergone a transformation in ownership to quasigovernment entities called airport authorities (Wells, 1999; Wells \& Young, 2004). Many people regard airports as public utilities; but on the contrary, airports are federally mandated to be self-sufficient and most do not usually receive any type of tax monies from their municipality (Wells \& Young, 2004). The management structures at airports do not follow any political mandate or local agenda and are run as a separate business enterprise (Rosado, 1997).

This study will identify which of the largest airports in the United States regularly undergo strategic planning processes. Of those airports, the research will present information relating to which jurisdictional type of airport ownership possesses the greater freedom to engage in strategic planning, and whether there is greater stability in airports that utilize strategic planning in lieu of the Federal Aviation Administration's (FAA) master planning mandate (FAA, 1985).

The next question will determine the flexibility of an airport's strategic plan and how the plan responded to the economic uncertainty beginning in 2000, including the events of 9/11. The financial downturn that followed the events of 9/11 was the worst in history for the airline and airport industry (Air Transport Association,
\end{abstract}


2002). Consumer confidence was shaken, and in turn, profitability and passenger spending was at an all-time low for the industry (Air Transport Association, 2002). This study will determine whether or not the nation's large hub airports have a flexible strategic plan in place, or if they had to develop and implement a new plan based on the events of the last three years.

This research focuses on the area of public and private organizations and the importance of strategic planning. As with many private entities, strategic planning should be viewed as a "best business practice" and should be used by all entities, regardless of profit motive or public service.

\section{BACKGROUND}

Strategic planning has been defined in a variety of ways by many researchers (Bozeman \& Straussman, 1990; Koteen, 1991; Nutt \& Backoff, 1992), and scholars and practitioners use slightly different definitions of the strategic planning process. However, the basic premise of strategic management includes three main processes: planning, resource allocation, and control and evaluation (Vinzant \& Vinzant, 1996).

Bryson (1988a) has described strategic planning as a disciplined effort to produce fundamental decisions and actions that shape and guide what an organization is, what it does and why it performs these actions. Strategic planning systems are part of an approach that uses functional divisions and operating units to develop detailed plans within the overall organization's plan for the future (Poister \& Streib, 1996).

Most of the theory and practice of strategic planning has been carried out in the private sector-- more specifically in the "for profit" sector. The initial area of public sector strategic planning was focused on the military (Bryson \& Roering, 1987). Strategic planning was then broadened to include the private sector and has been used to find the best fit between an organization and its surrounding environment (Bryson \& Roering, 1987). Most public sector organizations look to the private sector successes and try to adapt these methods to the public sector. With the ongoing public scrutiny of municipal agencies, the use of strategic planning has been gaining momentum within the public sector (Poister \& Streib, 1999).

Bryson and Roering (1987) suggest that strategic planning techniques developed in the private sector can help government entities become more effective, especially with their rapidly changing environments. Strategic planning has been mandated at the federal level by the Government Performance and Results Act of 1993 (GPRA), and many state governments have enacted similar statutes pertaining to strategic planning (Poister \& Streib, 1999).

This brings to the forefront the concept of municipal strategic planning. According to Poister and Streib (1999) "In the ongoing rush of activities, competing demands for attention, and the pressure of day-to-day decisions, focusing on a viable and responsive strategic agenda as the central source of direction, initiatives and priorities is of fundamental importance" ( $p$. 309). Municipal governments are under increasing stress stemming from the financial arena and citizens demanding more accountability and increased level of services from their local governmental units. One potential public management approach to reducing financial stress, while increasing accountability to the public, and using consumer input is to use strategic planning. BeckettCamrata (1998), Bryson (1995), and Streib and Poister (1990) have long argued that the government's uses of strategic planning benefits the public organization (Beckett-Camrata, 2003).

Airports are quasi-government entities because their ownership lies with cities, counties, states, and independent authorities. Large grants to public airports come through the Aviation Trust Fund, which is authorized by Congressional action and is administered by the Federal Aviation Administration (Wells, 1999; Wells \& Young, 2004). In order to qualify for federal funding the airport must have a current Airport Master Plan, which is a twenty-year capital investment (infrastructure) plan. The master plan is designed to address large capital investment, or construction projects (FAA, 1985).

Due to their independence from municipalities, many airports are operated as a 
public, "for profit" entity. As part of the FAA grant assurances, every airport that accepts public grants must strive to maintain selfsufficiency. Congress has also legislated that any and all monies derived from airport operations, cannot be diverted from the airport (FAA, 1999b). Along with legislating revenue diversion, most cities and counties do not financially support its airport's activities with general tax funds (Wells, 1999; Wells \& Young, 2004).

An airport should be viewed as an integral part of the total transportation system, consisting of physical components, owners and operators, controlling authorities, and the rules (federal and state) under which they operate (Caves \& Gosling, 1999). Equilibrium is hard to achieve in the airport area because of unsynchronized changes and different variables that influence the operation, as well as obvious tensions between the stakeholders (Caves \& Gosling, 1999). One can conceptualize strategic planning that encompasses all stakeholders and makes it possible to resolve conflicts and find overall operating efficiencies (Caves \& Gosling, 1999).

The FAA advocates strategic planning and sees it as a "thinking tool" to evaluate options and "what if" scenarios. It should be useful in developing and defending priorities and should be a corollary to business and marketing plans (Caves \& Gosling, 1999). Therefore, it seems airports should follow the best business practices derived from private business enterprises as well as instituting strategic planning processes.

\section{PURPOSE OF THE STUDY}

Because of the significance that strategic planning processes hold for leadership and management practices, this study may provide both theoretical and practical insight into the short- and long-term operations of commercial airports. The air transportation industry has been characterized as having a financial performance profile earmarked by extreme shifts of "boom and bust" (Kane, 2003). The most recent "bust" cycle provides an opportunity to investigate the organization and management of major airports via the strategic planning lens; this may provide a better understanding of the strengths and weaknesses of strategic management within the quasi-governmental sector. Additionally, the results of this investigation may contribute to the improvement of commercial airport performance and stimulate further research in airport management during an era of significant transformation.

\section{RESEARCH QUESTION}

The main research question will explore the relationship between strategic planning and airport ownership, performance, and operations. This research explored whether or not the largest 31 public-use airports in the United States have engaged in the strategic planning process and it also ascertained the overall effectiveness and flexibility of strategic planning in response to the current (2000-present) aviation economic crisis. Effectiveness and flexibility were reported by the respondents as determined by their particular situation.

\section{METHODOLOGY}

The data was collected as a crosssection of airport attitudes toward airport strategic planning. A survey was sent out to the entire population at the same time and the responses were measured, but at a single point in time. The data collection was accomplished via a self-administered questionnaire. The participating airports in this research were bounded by those airports categorized by the FAA as large hub airports, serving at least one percent of the total U.S. traveling public for the preceding calendar year. The contact information is readily available via the FAA's webpage, as well as the American Association of Airport Executives (AAAE) directory.

This research study adapted a 1990 survey used to assess strategic planning use in U.S. cities with populations from 25,000 to one million by Gregory Streib and Theodore Poister of Georgia State University. After reviewing current survey instruments previously used in gathering strategic planning information, a quantitative survey instrument was used. This instrument has been replicated by Streib and Poister over time and has demonstrated 
acceptable levels of validity and reliability. Although the current research adapted the instrument for use in hub airports, the integrity of the survey items remained intact. Nonetheless, the survey results were evaluated for acceptable validity and reliability.

The survey uses a 5 point rating (a Likert scale) yielding interval data; along with yes/no, or nominal data questions to be used for basic demographic information about the airport for categorization or grouping, and technical questions about the strategic planning processes employed by the entity. The technical questions were used to find descriptive information on the degree/level of strategic planning in use, as well as the overall satisfaction and effectiveness of the plan.

Certain ownership and management questions were asked to evaluate what typology of ownership best lends itself to effective strategic planning. The final stage of the instrument asked whether or not the airport followed their strategic plan on or around 9/11 and whether or not the airport stayed the course or changed their strategic plan in response to the terrorist events. A cover letter and survey was sent to the respective airport executives. There were no control groups utilized in this research study. The initial survey was distributed to each airport executive. Several airport executives filled the survey out personally, and others delegated the task to personnel in the airport planning department. Stakeholders outside airport management were not queried.

\section{DATA ANALYSIS}

In analyzing the survey results, descriptive statistics were used. The survey data were analyzed for the frequency distributions of certain coded data dealing with strategic planning and demographic data. Appropriate correlation analyses were used to examine any possible differences in the respondents' perceptions of strategic planning.

Cross tabulations and analysis of variance (ANOVA) were also utilized. Similarities and differences were discussed to determine which model of airport ownership is the most flexible and will lead to the most positive strategic planning.

Twenty-three of the possible 31 large hub airports responded to the survey, (74\% of the total population). Of the 23 airports that responded, 26\% enplaned between 7-11 million passengers; $52 \%$ enplaned between 12-20 million passengers; and $22 \%$ enplaned 21-40 million people per year. The largest group of respondents is reflected in the 12-20 millionpassenger range, which is to be expected, as there are few airports that enplane more than 20 million passengers each year (see Table 1)

Table 1: Large Hub Airport Passenger Enplanements

\begin{tabular}{|c|c|c|c|}
\hline & Airports & $\underline{\text { Percent }}$ & $\underline{\text { Cumulative Percent }}$ \\
\hline 7-11 Million & 6 & 26.1 & 26.1 \\
\hline 12-20 Million & 12 & 52.2 & 78.3 \\
\hline 21-40 Million & 5 & 21.7 & 100.0 \\
\hline Total & 23 & 100.0 & \\
\hline
\end{tabular}

As shown in Table 2, the airports represented all of the FAA's regions, except Alaska, with heavier concentration in the eastern (5) and southern (5) regions. This is attributable to the higher number of large hub airports in the New York and Florida areas. The three large hub airports in New York City are all owned and operated by the Port Authority of New York/New Jersey, two surveys were answered by the strategic planner and the third survey was completed by the airport's general manager.

The predominant form of ownership for those airports that responded was city-owned, at $43 \%$; other forms included airport authority $22 \%$; port authority (includes waterways) $13 \%$; county-owned nine percent; state-owned nine percent and one airport that is municipally owned, but independently operated at four percent as reported in Table 3. 
Table 2: Respondent Airports by FAA Designated Regions

\begin{tabular}{|c|c|c|c|}
\hline & \# of Airports & $\underline{\text { Percent }}$ & $\underline{\text { Cumulative Percent }}$ \\
\hline New England & 1 & 4.3 & 4.3 \\
\hline Eastern & 5 & 21.7 & 26.1 \\
\hline Southern & 5 & 21.7 & 47.8 \\
\hline Great Lakes & 1 & 4.3 & 52.2 \\
\hline Central & 2 & 8.7 & 60.9 \\
\hline Southwest & 2 & 8.7 & 69.6 \\
\hline Western Pacific & 4 & 17.4 & 87.0 \\
\hline Northwest Mountain & 3 & 13.0 & 100.0 \\
\hline Total & 23 & 100.0 & \\
\hline
\end{tabular}

Table 3: Respondent Airport by Type of Ownership

\begin{tabular}{lcc} 
& Frequency & Percent \\
\cline { 2 - 3 } City-owned & 10 & \\
County-owned & 2 & 8.7 \\
State-owned & 2 & 8.7 \\
Airport Authority & 5 & 21.7 \\
Port Authority & 3 & 13.0 \\
Municipal- & 1 & 4.3 \\
owned/independently & & \\
operated & & \\
Total & 23 & 100.0 \\
\cline { 2 - 3 }
\end{tabular}

The Federal Aviation Administration mandates that airports undergo master planning, which equates to a long-term capital improvement infrastructure plan. Any airport that wishes to apply for federal funds is required to compile such a plan. Of the 23 airports that

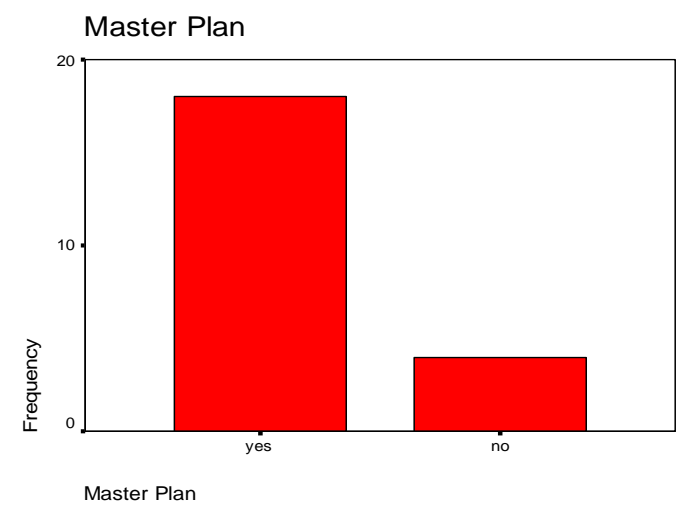

Figure 1: Airports with a Master Plan

Airports were also asked how long there had been strategic planning within their entity; two airports reported less than one year of strategic planning; five airports reported they had been planning for one to three years; six airports had undergone strategic planning for four to six years; and the majority, eight airports,

\begin{tabular}{c} 
Cumulative Percent \\
\hline 43.5 \\
52.2 \\
60.9 \\
82.6 \\
95.7 \\
100.0
\end{tabular}

responded, 18 have a master plan, four airports do not have a current master plan and one airport did not respond to the question. Of those same airports, 18 have a working strategic plan and five do not, as shown in Figures 1 and 2.

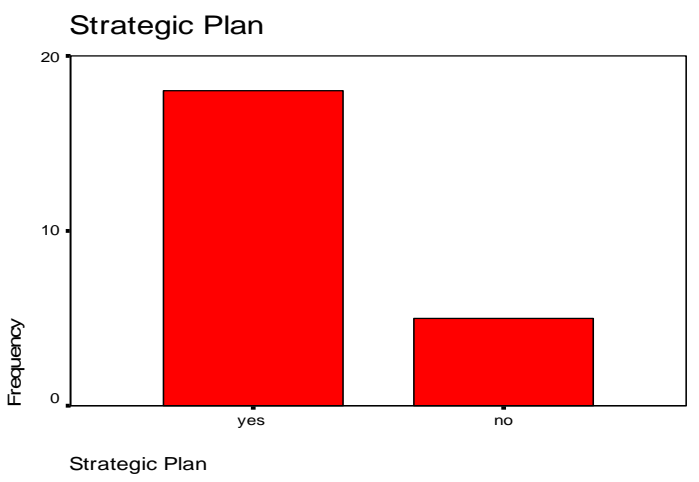

Figure 2: Airports with a Strategic Plan had been engaged in strategic planning for more than six years. Two airports did not report this data; it would seem plausible to assume that these two airports do not have a strategic plan in place. See Figure 3 for the strategic planning breakdown, including airports reporting less than one year. 
The airports were asked to what extent they were satisfied with the implementation and achievement of the strategic planning goals and objectives. Fifteen airports reported that they were satisfied or very satisfied with results thus far; five airports were not sure to what degree they were satisfied; one airport was dissatisfied; and two airports did not answer the question (see Figure 4).The next question asked was how much the overall effectiveness of the airport had improved as a result of strategic planning. Sixteen airports, or $70 \%$, indicated there was moderate to significant improvement with the strategic plan in place. Five airports, or $21 \%$ of the sample size, indicated minimal to no improvement and two airports did not answer the question (see Table 4)

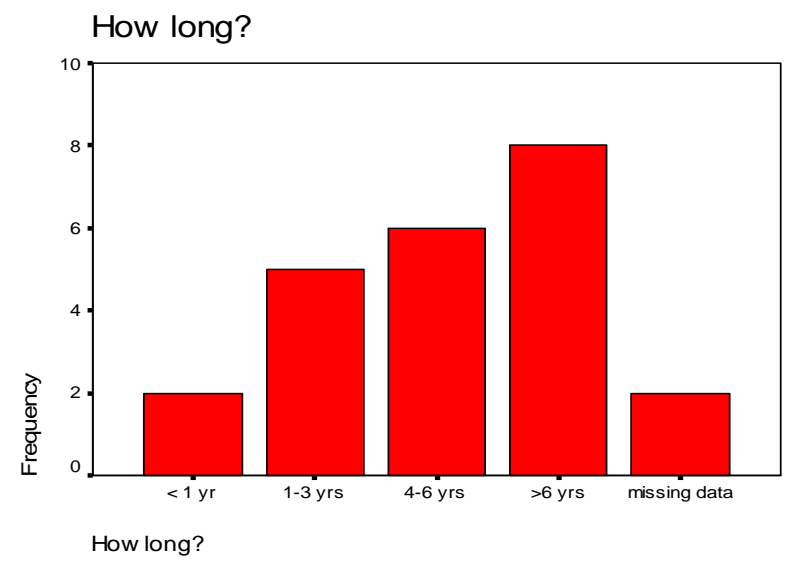

Figure 3: Length of Time an Airport has been Engaged in Strategic Planning

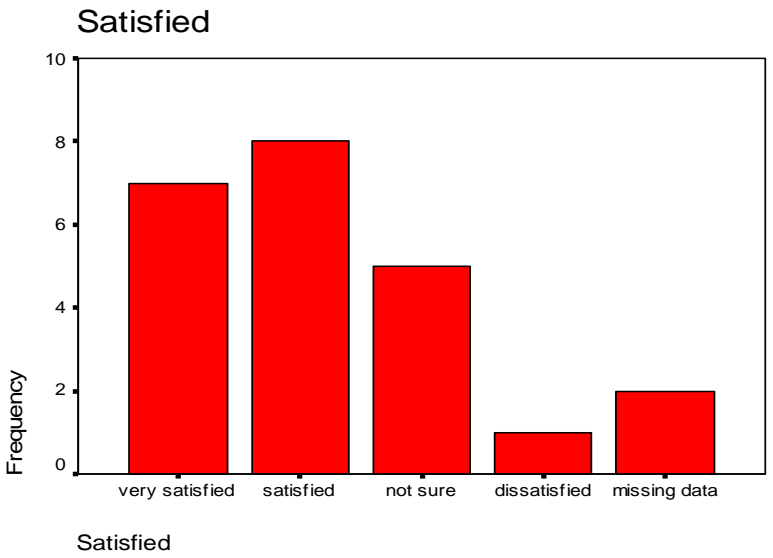

Figure 4: Satisfaction of Implementation and Achievement of Strategic Plan 
Table 4: Improved Overall Effectiveness with Implementation of Strategic Plan

\begin{tabular}{|c|c|c|c|}
\hline & $\underline{\text { Frequency }}$ & $\underline{\text { Percent }}$ & $\underline{\text { Cumulative Percent }}$ \\
\hline No improvement & 3 & 13.0 & 13.0 \\
\hline Minimal improvement & 2 & 8.7 & 21.7 \\
\hline Moderate improvement & 6 & 26.1 & 47.8 \\
\hline Significant improvement & 10 & 43.5 & 91.3 \\
\hline missing data & 2 & 8.7 & 100.0 \\
\hline Total & 23 & 100.0 & \\
\hline
\end{tabular}

The airports were asked whether the

the question, but as seen in Figure 5, 12 airports or $52 \%$ of the responding airports, agreed or strongly agreed that the strategic plan in place during the events of 2000 was flexible enough to steer the airport through this difficult economic period. strategic plan that was in place during the economic downturn of 2000 and the terrorist events of 9/11/01 was flexible enough to guide the airport during the past four years. Three airports, or $13 \%$ of the sample, did not answer

Flex/911

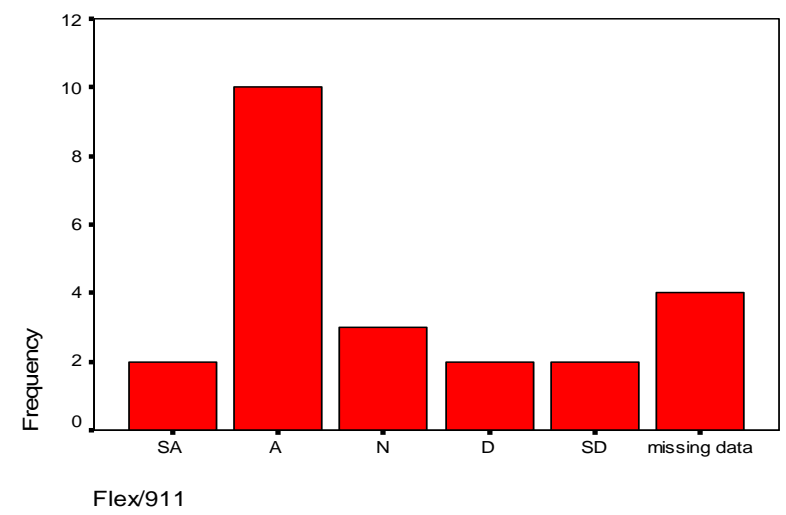

Figure 5: Flexibility of Strategic Plan with 9/11

Cross tabulations were used on several of the survey questions to compare two classification variables. The first two variables chosen were the type of airport ownership structure and whether or not the airport has a strategic plan in place. Table 5 depicts the ownership structure compared to the strategic plan variable. The municipally owned airports (city/county) account for the bulk of the respondents and also carry out the most strategic planning. Nine of 12 municipally owned airports engage in strategic planning. Of the authorityrun airports (airport and port), six of eight engage in strategic planning compared to $100 \%$ of the state-run airports.

\section{Table 5: Cross Tabulation of Airport Ownership and Strategic Planning}

\begin{tabular}{lccc} 
& Strategic Plan & & Total \\
\cline { 2 - 4 } City & $\frac{\text { yes }}{8}$ & $\frac{\text { no }}{2}$ & 10 \\
County & 1 & 1 & 2 \\
State & 2 & & 2 \\
Airport Authority & 3 & 2 & 5 \\
Port Authority & 3 & & 3 \\
Municipally owned/independently operated & 1 & & 1 \\
\cline { 2 - 4 } Total & 18 & 5 & 23
\end{tabular}


The next cross tabulation is a combination of whether or not the airport has a strategic plan, and if there has been improved effectiveness as a result of implementing the plan. Of the 18 airports with a strategic plan, 16 report moderate to significant improvement. Of the five airports that do not have a strategic plan, three airports report no improvement, and two airports did not answer the question (see Table $6)$.

Table 6: Cross Tabulation of Strategic Plan and Improved Effectiveness

\begin{tabular}{|c|c|c|c|c|c|c|c|}
\hline & & $\begin{array}{c}\text { Improved } \\
\text { Effectiveness } \\
\text { none }\end{array}$ & $\underline{\text { minimal }}$ & $\underline{\text { moderate }}$ & $\underline{\text { significant }}$ & $\frac{\text { missing }}{\text { data }}$ & Total \\
\hline$\frac{\text { Strategic }}{\text { Plan }}$ & yes & & 2 & 6 & 10 & & 18 \\
\hline & no & 3 & & & & 2 & 5 \\
\hline Total & & 3 & 2 & 6 & 10 & 2 & 23 \\
\hline
\end{tabular}

The next cross tabulation performed looked at the variables of ownership and how long it has been engaged in strategic planning. Eight of the 23 airports have been engaged in strategic planning for more than six years. Six airports have been using strategic planning for four to six years and five airports have been planning for one to three years, with two airports utilizing the planning process for less than one year and two airports who did not report their status. The ownership type does not seem significant for those airports that have been engaged in planning any longer than any other airport, as shown in Table 7.

Table 7: Cross Tabulation of Airport Ownership and Length of Strategic Planning

\begin{tabular}{|c|c|c|c|c|c|c|c|}
\hline & & $\begin{array}{l}\text { How } \\
\text { long? } \\
<1 \mathrm{yr}\end{array}$ & $1-3 \mathrm{yrs}$ & $4-6 \mathrm{yrs}$ & $\geq 6$ yrs & missing data & Total \\
\hline \multirow[t]{6}{*}{ Ownership } & City & 2 & 2 & 2 & 3 & 1 & 10 \\
\hline & County & & 1 & 1 & & & 2 \\
\hline & State & & & 2 & & & 2 \\
\hline & $\begin{array}{l}\text { Airport } \\
\text { Authority }\end{array}$ & & 1 & 1 & 2 & 1 & 5 \\
\hline & Port & & 1 & & 2 & & 3 \\
\hline & $\begin{array}{l}\text { Muni/indep } \\
\text { endent } \\
\text { operated }\end{array}$ & & & & 1 & & 1 \\
\hline Total & & 2 & 5 & 6 & 8 & 2 & 23 \\
\hline
\end{tabular}

The final cross tabulation ran three separate variables: number of passengers, whether or not the airport has engaged in strategic planning, and financial performance of the airport. According to federal guidelines, all public-use airports that receive government financial subsidies must submit an income statement each year that is accessible through the Federal Aviation Administration's web page. This is carried out through the FAA's Airport
Compliance Division, AAS-400, and can be accessed via www.faa.gov/arp. According to the FAA, "The Airport Financial Reporting Program is an outgrowth of the FAA Authorization Act of 1994, which requires commercial service airports to file annual financial reports with the FAA" (FAA, n.d.). The airport financial reporting website is maintained by Crown Consulting, and the host site is http://cats.crownci.com. 
Financial information relative to the specific airports that filled out the survey was accessed via http://cats.crownci.com/ reports/rpt127.cfm. Net income/loss was used as the financial measure, including aeronautical revenue, non-aeronautical revenue (terminal) and non-operating revenue, along with operating expenses, non-operating expenses and depreciation. An airport's financial instruments were not used in the calculation, as every airport has a unique bonding situation.

Table 8 shows the relationship between those airports with a strategic plan in place and the number of passenger enplanements, as this can affect revenues and expenses, along with each airport's specific net income/loss situation. The analysis shows that the number of passengers processed by the airport is particularly important in relation to gross revenue. This type of report follows the government format for financial reporting, rather than the usual format used by private enterprises. The airport reports operating and non-operating revenues, less the operating and non-operating expenses, with the remainder is referred to as "net," which could mean revenue or loss not specifically tied to income. The airport's financial instruments are not utilized to calculate this number.

Of the 18 airports that engage in strategic planning, 11 report net revenue of more than 50 million dollars; the five airports that do not engage in strategic planning report net revenue of zero to 50 million. Two airports reported a negative "net" for the year 2003. Of those airports that had higher net revenue, seven enplane between 12 and 20 million passengers per year, and four enplane 21 to 40 million passengers per year.

\section{Table 8: Cross Tabulation of Passengers/Strategic Plan/Financial Performance}

$\begin{array}{lcr}\begin{array}{l}\text { Financial } \\ \text { Performance } \\ \text { - Revenue }\end{array} & \text { Passengers } & 12-20 \mathrm{M} \\ & \text { Total } & 21-40 \mathrm{M} \\ & \text { Passengers } & 7-11 \mathrm{M} \\ \text { 0-\$50M } & \text { Total } & 12-20 \mathrm{M} \\ & \text { Passengers } & 12-20 \mathrm{M} \\ \text { \$50-100M } & \text { Total } & 21-40 \mathrm{M} \\ & \text { Passengers } & 12-20 \mathrm{M} \\ \text { \$100-150M } & \text { Total } & 21-40 \mathrm{M} \\ & \text { Passengers } & 12-20 \mathrm{M} \\ >\text { \$150M } & \text { Total } & 21-40 \mathrm{M} \\ & & \end{array}$

A one-way analysis of variance (ANOVA) test was conducted on the Likert Scale data in the survey, the dependent variables were: passenger enplanements (three groups), region where the airport resides (nine groups), and ownership structures (six groups) these data were analyzed with the Likert scale questions on the instrument. The ANOVA revealed no significant difference between any of the groups. The level of significance ranged from .608 to

$\begin{array}{ccc}\begin{array}{c}\text { Strategic Plan } \\ \text { yes }\end{array} & \text { no } & \text { Total } \\ & & \\ 1 & & 1 \\ 1 & & 2 \\ 2 & & 6 \\ 2 & 4 & 4 \\ 3 & 1 & 10 \\ 5 & 5 & 4 \\ 4 & & 1 \\ 1 & & 5 \\ 5 & & 2 \\ 2 & & 1 \\ 1 & & 3 \\ 3 & & 2 \\ 1 & & 3 \\ 2 & & \end{array}$

.680 for the number of passengers enplaned per the Likert Scale questions in the survey. The level of significance for the groups based on ownership structures and the Likert Scale questions ranged from .542 to .804 , and the variable of airport region and the Likert Scale questions level of significance was .795 to .902 . This observation is quite strong for the size of the sample. However, the overall number of airports nationwide is much larger than this 
sample.

The fact that there are no significant differences between groups is assumed to mean that there is no difference between size of airports, their specific location in the United States and what type of ownership structure exists. Basically, regardless of size, location and ownership, all large hub airports are operated about the same. Most airports report satisfaction with strategic planning and a belief in the process, so there is obviously a positive link between planning and performance. No factors were identified as to why one airport would engage in strategic planning and another would not.

\section{GENERAL CONCLUSIONS}

As expected, the majority (52\%) of the airports that were represented in the data set were city- or county-owned. This is the predominant form of ownership in the United States as reported by the federal government and Wells and Young (2004). However, a close second type of ownership is the airport/port authority, semi-independent ownership structure, representing $35 \%$ of the respondents.

An interesting point to note is the number of airports that have a working master plan, as mandated by the FAA for receipt of funding, was the same as those airports that reported having an operating strategic plan. Seventy-eight percent of the airports reporting have a master plan and strategic plan in place. In Berry and Wechsler's survey of 1995, 60\% of state agencies reported using some form of strategic planning, and Poister and Streib (1994) reported that nearly $60 \%$ of municipal managers were engaged in some form of planning. The obvious trend is that strategic planning initiatives are increasing with time.

When asked how long the airports have been engaged in strategic planning, four airports reported they were engaged in their first effort, and one airport reported there was no strategic planning process in place. As anticipated by state government mandate, the two airports that are owned by their respective state do have a strategic plan in place. To answer the first question of the research, the majority of large hub airports engage in strategic planning, some through mandate, but the majority voluntarily.

Sixty-one percent of the airports reported being engaged in strategic planning for four years or more. This would signal that most airports began the strategic planning initiative slightly before the economic downturn of 2000 . Airports seem to lag behind private and public entities in their initiation of the strategic planning effort. Sixty-five percent of the airports reported being satisfied or very satisfied with their strategic planning efforts to date. The other $35 \%$ were unsure, dissatisfied or simply did not answer the question. It would appear that more than half of the airports are satisfied with their efforts, while the remainder may be quite new to the process, as $39 \%$ of the airports have either had a strategic plan for less than three years or did not answer the question. Those that did not answer the question could indicate an airport without a strategic plan or a plan that is not effective.

Seventy percent of the respondents report they have experienced moderate to significant improved effectiveness upon implementation of their strategic plan. Thirteen percent reported no improvement, and nine percent of the group reported minimal improvement, or did not answer the question. It appears that the airports that have a strategic plan up and running for more than four years have seen moderate to significant improvement in the effectiveness of their operation.

However, the flexibility of the plan to meet the needs of the airport for the economic downturn of 2000 and the events of 9/11 did not have resounding numbers when compared to earlier questions. Fifty-two percent of the group felt that their plan was flexible enough to guide the airport through the next few years, while 11 airports (48\%) did not agree with the statement and chose neutral or disagree, or left the question unanswered.

In order to determine which ownership structure lends itself best to strategic planning, it appears that those airports not engaged in strategic planning are evenly distributed between city, county and airport authority ownership types. An expectation of the study was that more independent authority ownership structures were more likely to take on strategic planning. As 
earlier identified, those airports under state ownership are actively engaged in strategic planning.

It appears that the longer the airport is engaged in strategic planning, the higher the satisfaction is achieved. Of the eight airports engaged in strategic planning for more than six years, only one airport is dissatisfied with the strategic plan. Therefore, $88 \%$ of the airports that have been engaged in strategic planning for more than six years are satisfied or very satisfied with their plan. Five airports reported they were unsure of their satisfaction level with their plan, and four of those airports have been planning four years or less. It seems obvious that the longer the strategic plan is in place, the higher the level of satisfaction.

When researching whether there were differences among the airports based on their passenger enplanements, region of the United States or ownership structure, it appears from the ANOVA tests that no significant difference exists between the groups; therefore, it safe to say that whether the airport enplanes seven or 40 million, resides in the New England area or the Western Pacific, and is owned by a city, state or independent authority, the large hub airports in the United States are similar in operation and performance. Correspondingly, Streib and Poister (1990) reported that strategic planning did not vary significantly by city size or form of government.

The final analysis is self-reported effectiveness. Since there is no one best definition of effectiveness, the airports were asked to describe their concept of effectiveness. The answers ranged from reaching the mission and vision of the organization to improving the bottom line. Most airports want to control their cost structures while offering superior customer service to passengers and tenants, and accomplishing established goals and objectives. There again, it appears that effectiveness has different meanings to different organizations, and each organization must define what effectiveness will mean in a particular situation. It is not a term that can be predefined for any one organization, as there is no universal fit. "Porter says effectiveness resides in strategy" (Mintzberg, 1991, p. 54).
Mintzberg (1994) and Bryson (1995) say there is no one perfect strategic planning process that fits all and most organizations need to find their specific niche or fit. As Caves and Gosling (1999) indicate, equilibrium is hard to achieve in the airport area, because of unsynchronized changes and different variables influencing the operation, and obvious tensions between the stakeholders.

Finally, to answer the research questions posed earlier, the data clearly indicates that the majority of large hub airports engage in strategic planning and that their plan has proven to be flexible enough to guide the airport through difficult economic times. Most airports indicated their strategic plan is effective. Since there is no single standard measure of effectiveness available, each airport, with its set of individual circumstances, stated their own definition of plan effectiveness. As each organization charts its own strategic plan, so must each organization define its overall plan effectiveness.

\section{RECOMMENDATIONS}

The information gathered in this study illustrates the importance of strategic planning and the subsequent implementation of the plan. Regardless of airport ownership structure, the overall importance of a solid strategic plan is evident. The majority of airports surveyed reported that their strategic plan is flexible and has improved the organization's overall effectiveness. The past four years have been economically challenging for the aviation industry, therefore strategic planning becomes a necessity for an airport to remain self-sufficient. 


\section{REFERENCES}

Air Transport Association (ATA). (2002). The perfect economic storm: the airlines in crises. Retrieved on March 11, 2004 from: www.airlines.org/

Al-Garni, S.A. (1997). The role of strategic planning in improving public organizations' performance. Unpublished Ph.D. Dissertation. University of Colorado at Denver. (UMI No. 9813085).

Baile, K.C. (1998). A study of strategic planning in federal organizations. Unpublished Ph.D. Dissertation. Virginia Polytechnic Institute and State University. (UMI No. 9957067).

Beckett-Camrata, J. (2003). An examination of the relationship between the municipal strategic plan and the capital budget and its effect of financial performance. Journal of Public Budgeting, Accounting \& Financial Management. 15(1), 23-35.

Berry, F.S. \& Wechsler, B. (1995). State agencies' experience with strategic planning: Findings from a national survey. Public Administration Review, 55, 159-169.

Bryson, J.M. \& Einsweiler, R.C. (1987). Strategic planning. Journal of the American Planning Association. 53(1), 6-9.

Bryson, J.M. \& Roering, W.D (1987). Applying private sector strategic planning in the public sector. Journal of American Planning Association. 53(1), 9-22.

Bryson, J.M. (1988a). Strategic planning for public and nonprofit organizations: a guide to strengthening and sustaining organizational achievement. San Francisco: Jossey-Bass.

Bryson, J.M. (1988b). A strategic planning process for public and non-profit organizations. Long Range Planning. 21(1) 73-81.

Bryson, J.M. (1995). Strategic planning for public and nonprofit organizations: a guide to strengthening and sustaining organizational achievement. (Revised edition). San Francisco: Jossey-Bass.

Caves R.E. \& Gosling, G.D. (1999). Strategic airport planning. Amsterdam: Pergamon.

Coolbaugh, J.D. (1994). An analysis of strategic planning in California cities. Unpublished Ph.D. Dissertation. University of LaVerne. (UMI No. 9426151).

deNeufville, R., \& Odoni, A. (2003). Airport systems: planning, design and management. New York: McGraw-Hill.

Federal Aviation Administration. (1985). Advisory circular: airport master plans. 150/5070-6A. (Publications Section M-442-32).

Federal Aviation Administration (FAA). (1999). Airport business practices and their impact on airline competition. October. FAA/OST Task Force.

General Accounting Office. (2004, March). GPRA provides foundation for results-oriented government. Publication No. GAO-04-38. Retrieved on March 14, 2004, from: http://www.gao.gov/cgibin/getrpt?GAO-04-38. 
Gesell, L.E. (1999). The administration of public airports. (4th ed.). Chandler, AZ: Coast Aire Publications. Kane, R.M. (2003). Air transportation. (14 $4^{\text {th }}$ ed.). Dubuque, IA: Kendall/Hunt.

Mintzberg, H. (1991). The effective organization: forces and forms. Sloan Management Review. 32(2).

Mintzberg, H. (1994). The rise and fall of strategic planning: reconceiving roles for planning, plans, and planners. New York: The Free Press.

Poister, T.H. \& Streib, G. (1994). Municipal management tools from 1976 to 1993: An overview and update. Public Productivity \& Management Review. 11(3) 115-125.

Poister, T.H. \& Streib, G. (1996.) Strategic planning: a core responsibility of local government administrators. In (ed) John J. Gargan. Local Government Management. Marcel Deceker.

Poister, T.H. \& Streib, G. (1999). Strategic management in the public sector: concepts, models and processes. Productivity \& Management Review. 22(3), 308-325.

Rosado, A. (1997). Strategic choice in government owned enterprises: the association between characteristics of airport senior executives and strategic decisions made at small and non-hub airports. (UMI No. 9813346).

Steiner, G. \& Miner, J.B. (1977). Management policy and strategy. New York: Macmillan.

Streib, G. \& Poister, T.H. (1990). Strategic planning in u.s. cities: patterns of use, perceptions of effectiveness, and assessment of strategic capacity. American Review of Public Administration, 20(1), 29-44.

Vinzant, D.H. \& Vinzant, J.C. (1996). Strategy and organizational capacity: finding a fit. Public Productivity \& Management Review. 20(2), 139-157.

Wells, A.T. (1999). Airport planning and management. (4 ${ }^{\text {th }}$ ed.). New York: McGraw-Hill.

Wells, A.T. \& Young, S. B. (2004). Airport planning and management. (5 ${ }^{\text {th }}$ ed.). New York: McGraw-Hill. 